Int. Archs Allergy appl. Immun. 1986;79:I-V

\title{
Contents, Vol. 79, 1986
}

\section{No. 1}

Original Paper

Augmentation of Natural Killer Cytotoxicity by Alpha or Gamma Natural and Recombinant Interferons and Inter-feron Inducers. Effect of Monocytes Platsoucas, CD.; Fernandes, G.; Good, R.A.; Gupta, S. . 1

Antagonism of Antigen-Induced Contraction of Isolated

Guinea-Pig Trachea by 5-Lipoxygenase Inhibitors

Hand, J.M.; Schwalm, S.F.; Lewis, A.J 8

Specific Plasma Cell Accumulation in Antigen-Induced Chronic Inflammation in the Guinea Pig Peritoneal Cavity van Dinther-Janssen, A.C.H.M.; Hofland, L.; Scheper, R.J. 14

Characterization of an Antigen from Rat Male Accessory Glands

Pesoa, S.A.; Galmarini, M.; Pistoresi-Palencia, M.C.; Riera,

CM 19

Kinetics of Cells in the Intestinal Mucosa of Mice following

Oral Infection with Ancylostoma ceylanicum

Carroll, S.M.; Grove, D.I.; Heenan, PJ 26

In vitro Appearance of Large Human Histamine Containing Basophilic Cells

Ahlstedt, S.; Hammarström, I.; Into-Malmberg, M.-B.;

Björkstén, B.; Denburg, J 33

Role of Leukotrienes in Rat Reversed Passive Arthus Pleurisy

and the Effect of AA-861, a 5-Lipoxygenase Inhibitor

Makino, H.; Ashida, Y.; Saijo, T.; Kuriki, H.; Terao, S.;

Maki, Y 38

Synergism between Gammaglobulin Prophylaxis and Penicillin Treatment in Experimental PostSplenectomy Sepsis in the Rat Oflenbartl, K.S.; Christensen, P.; Gullstrand, P.; Prellner, K. 45 Studies on Monovalent Anaphylactogens with Carbohydrate

Auxiliary Groups: Exclusion of an Artefact

Guenin, R.; Schneider, C.H 49

Human Antibodies against Formaldehyde-Human Serum Albumin Conjugates or Human Serum Albumin in Individuals Exposed to Formaldehyde Patterson, R.; Pateras, V.; Grammer, L.C;

Harris, K.E. . 53

Demonstration of Close Physicochemical Similarity and Partial

Immunochemical Identity between the Major Allergen,

Dp42, of the House Dust Mite, D. pteronyssinus and Corre

sponding Antigens of D. faunae (Df6) and D. microceras

(Dm6)

Lind, P 60 
Antibody Responses of Mice to Intragastric and Parenterally

Administered Aeroallergens

Henderson, D.C; Moran, D.M

66

Persistence of Hemoglobin Allergenicity and Antigenicity dur

ing Metamorphosis of Chironomidae (Insecta: Diptera)

Prelicz, H.; Baur, X.; Dewair, M.; Tichy, H.; Kay, A.B.;

Tee, R.; Cranston, P.S 72

Phthalic Anhydride-Induced Occupational Asthma

Wernfors, M.; Nielsen, J.; Schütz, A.; Skerfving, S 77

Further Studies on the Ability of Different Metal Salts to

Influence the DNA Synthesis of Human Lymphoid Cells

Nordlind, K 83

Modulation of Adjuvant-Enhanced Delayed-Type Hypersensi-tivity by the Interferon Inducers

Poly I:C and Newcastle Disease Virus

Kraaijeveld, C.A.; Kamphuis, W.; Benaissa-Trouw, B.J.;

Harmsen, M.; Snippe, H 86

IgE Responses of Wistar Rats to Schistosoma mansoni Infec

tions

Reiner, G.; Zahner, H 90

Avian Immune Capacity and Bone Marrow Cellularity after in

ovo Treatment with Cyclophosphamide

Glick, B 95

Antigenic and Allergenic Determinants of Ovalbumin. I. Pep-tide Mapping, Cleavage at the

Methionyl Peptide Bonds and Enzymic Hydrolysis of Native and Carboxymethyl OA

Elsayed, S.; Hammer, A.S.E.; Kalvenes, M.B.; Florvaag, E.;

Apold, J.; Vik, H 101

Effect of Platelet-Activating Factor (PAF) on Human Cardiac Muscle

Alloatti, G.; Montrucchio, G.; Mariano, F.; Tetta, C; De

Paulis, R.; Morea, M.; Emanuelli, G.; Camussi, G 108

News Item 100

No. 2

Original Paper

Cl Activation, with Clq in Excess of Functional Cl in Synovial

Fluid from Patients with Rheumatoid Arthritis

Sjöholm, A.G.; Berglund, K; Johnson, U.; Laurell, A.-B.;

Sturfelt, G 113

Identification of Parietaria judaica Pollen Allergens

Ford, S.A.; Baldo, B.A.; Geraci, D.; Bass, D 120

The Effect of Some Immunomodulating Agents on the Sensiti-

zation Phase of Experimental Contact Allergic Reactions

Anderson, C 127

IV

Contents

Assessment of Skin Reactivity and Specific Antibody to Egg and Milk Proteins in Patients with Atopic Dermatitis: 
Comparison with Responses to the House Dust Mite Anti

gen

Rowntree, S.; Mitchell, E.B.; Platts-Mills, T.A.E 132

A Thin Gel Layer Technique for Improved Resolution in Two-

Dimensional Immunoelectrophoresis

Samuelson, L 140

Selective Enzyme Staining Procedures of Characterization of

Mycobacterial Immunoprecipitates

Öhman, R.; Ridell, M 145

Autoantibodies of the IgM Class against a Human Myeloma

Protein IgE (DES). I. Occurrence

Magnusson, C.G.M.; Vaerman, J.P 149

Autoantibodies of the IgM Class against a Human Myeloma

Protein IgE (DES). II. Specificity

Magnusson, C.G.M.; Vaerman, J.P 157

Cyclosporin A-Induced Suppression of Ongoing IgE Antibody Formation in the Mouse

Okudaira, H.; Sakurai, Y.; Terada, K.; Terada, E.; Ogita, T.;

Miyamoto, T 164

P Cell Stimulating Factor Release: A Useful Assay of T Cell Activation in vitro

Fazekas de St. Groth, B.; Thomas, W.R.; McKimm-Bresch-kin, J.L.; Clark-Lewis, I.; Schrader, J.W.; Miller, J.F.A.P.. 169

Low Molecular Weight Eosinophil Chemotactic Factor (ECF)

in the Serum of Murine Schistosomiasis Japonica

Owhashi, M.; Horii, Y.; Ishii, A.; Nawa, Y 178

T Cell Subsets in Idiopathic Glomerulonephritis

Patel, R.; Connor, G.; Patel, D.R.; Soriano, A.; Najera, D. 182

A Genetic-Epidemiologic Study of Human Immune Respon

siveness to Allergens in an Industrial Population. III. Envi

ronmental Influences on Skin Sensitivity and Total Serum

IgE in a Stratified Random Sample

Freidhoff, L.R.; Meyers, D.A.; Marsh, D.G 188

Antigenic Competition in IgE Antibody Production. III. Sup-pressive Effect on Th and B Cells

Soares, M.F.M.; Macedo, M.S. de; Perini, A.; Mota, I. . . 196

Tolerogenic Properties of Human IgG Subclasses in Mice

Huchet, R 202

Induction of IgE Antibody Production to Aerosolized Ovalbu-min in Mice Treated

Intratracheally with Aluminum Silicate

Fujimaki, H.; Ozawa, M.; Ashikawa, T.; Kubota, K.; Wata-

nabe, $\mathrm{N} 206$

Tolerance to the Trinitrophenol Ligand in Guinea Pigs: Studies

on the Role of the Solvent Used in Feeding

Pomeranz, J.R 211

Short Communications

Characterisation of Cyclosporine-Induced Suppressor Cells in Murine Delayed-Type

Hypersensitivity Responses Mirisklavos, A.; Mottram, P.L.; Dumble, L.J.; Clunie, GJ.A. 215 
Plasma Protease Inhibitor and Anaphylatoxin Inactivator Levels in Chronic

Urticaria/Angioedema and in Patients Experiencing Anaphylactoid Reactions to Radiographic Contrast Media Mathews, K.P.; Pan, P.M.; Amendola, M.A.; Lewis, F.H. 220

Book Reviews 224

No. 3

Original Paper

Paradoxical Augmentation of Tuberculin-Like Hypersensitivi

ty, but Not Jones-Mote of Contact Hypersensitivity, in

Cyclosporin A Treated Guinea Pigs

Aldridge, R.D.; Thomson, A.W 225

The Antiallergic Agent Amoxanox Suppresses SRS-A Generation by Inhibiting Lipoxygenase

Saijo, T.; Makino, H,; Tamura, S.; Kuriki, H.; Ashida, Y.;

Terao, S.; Maki, Y 231

Identification of Main Allergens from Dermatophagoides fa

unae and their Properties under Native and Dissociating

Conditions

de la Hoz, F.; Carreira, J 238

Allergic Bronchopulmonary Aspergillosis in Asthmatic Pa

tients Presenting with Allergic Rhinitis

Grammer, L.C.; Greenberger, P.A.; Patterson, R 246

Effects of Hi and H2 Receptor Agonists on Nonspecific Proliferative Response of Human Peripheral Blood Lympho

cytes

Beaulieu, L.; Beaudoin, J.; Jobin, M.; Hébert, J 249

Effect of TMB-8 on Histamine Release from Isolated Rat Mast

Cells

Grosman, N 253

IgE Antibodies against Piperazine and N-Methyl-Piperazine in

Two Asthmatic Subjects

Welinder, H.; Hagmar, L.; Gustavsson, C 259

A Partially Purified Glycoprotein Antigen from Aspergillus fumigatus

Kurup, V.P.; John, K.V.; Resnick, A.; Fink, J.N 263

Bile and Milk from Cholera Toxin Treated Rats Contain a Hor

mone-Like Factor Which Inhibits Diarrhea Induced by the

Toxin

Lange, S.; Lönnroth, $1 \quad 270$

Limiting Dilution Analysis of Age- and Gender-Related Differ

ences in Autoantibody Production against Bromelain-Mod-

ified RBC

Errington, S.L.; Cox, K.0 276

Extensive Cross Reactivity between Treponema pallidum and

Cultivable Treponemes Demonstrated by Sequential Im-

munoadsorption

Wos, S.M.; Wicher, K282 
In vivo Reduction of Circulating Clq Binding Immune Com plexes by Intravenous Gammaglobulin Administration

Lin, R.Y.; Racis, S.P 286

Cyclophosphamide-Mediated Enhancement of Delayed Hyper

sensitivity Reactions in the Lung (with 1 color plate)

Enander, I.; Ahlstedt, S.; Nygren, H 291

Effects of Cyclosporin A, Antilymphocyte Serum and Donor-Specific Transfusions on Murine Delayed-Type Hypersensitivity and Skin Graft Survival Mottram, P.L.; Mirisklavos, A.;

Dumble, L.J.; Clunie, G.J.A. 296

Augmentation of Human Polymorphonuclear Leukocyte Ad

herence by Interferon

Seow, W.K.; Thong, Y.H 305

Partial Separation and Functional Characterization of Guinea

Pig Basophil-Stimulating Factor

Denburg, J.A.; Davison, M.; Bienenstock, J 312

Enander/Ahlstedt/Nygren

Fig. 4. Section of mouse lung stained with periodic-acid Schiff reagent in combination with toluidine blue stain, a Control mice. No mucus-producing cells can be seen, b PiCl-sensitized mice. Increased mucus-producing cell differentation. c Cy-treated and PiCl-sensitized mice. Pronounced increase of mucus-producing cell differentiation.

Int. Archs Allergy appl. Immun., Vol. 79 S. Karger, Basel

Contents

$\mathrm{V}$

Induction of a Protective Immune IgE Response in Rats by Injection of Defined Antigens of Schistosomulum-Released Products: Immunochemical Properties of the Target Antigens

Damonneville, M.; Auriault, C; Thorel, T.; Verwaerde, C;

Pierce, A.; Strecker, G.; Capron, A 320

Short Communications

Induction of IgE-Secreting Cells in the Lymphatic Drainage of

the Lungs of Rats following Passive Antigen Inhalation

Sedgwick, J.D.; Holt, P.G . 329

Dispersion and Characterisation of Mast Cells from Human Skin Benyon, R.C.; Church, M.K.;

Clegg, L.S.; Holgate, S.T. . 332

Book Reviews $\quad 335$

No. 4

Original Paper

Regulation of in vivo IgE Biosynthesis in Mice with Complete

Freund's Adjuvant

Smith, W.G.; Butchko, G.M 337

Measurement of Specific IgG Antibody Levels in Serum of

Patients on Regimes Comprising High Total Dose Beta-

Lactam Therapy

Lee, D.; Dewdney, J.M.; Edwards, R.G.; Neftel, K.A.;

Wälti, M 344

Detection of an IgM Antiglobulin in the Sera of Atopic Patients 
Using Insolubilised IgG4, and its Capacity to Release His-

tamine from Leukocytes

Shakib, F.; Morrow Brown, H.; Phelps, A.; Redhead, R. . 349 The Excretion of IgE with Feces

from Healthy Individuals and

from Others with Allergy and Diseases Affecting the Intestinal Tract

Kolmannskog, S.; Florholmen, J.; Flægstad, T.; Kildebo, S.;

Haneberg, B 357

Cell Labeling and Sorting by Rosette Formation. Use of Biotin-

Avidin Binding

Owen, C.S.; Rothong, C.L 365

Activation of Effector Cells of Experimental Allergic Encepha-

lomyelitis in Lewis Rats: Comparison of T-Cell Lines with

Primary Cultured Lymph Node Cells

Namikawa, T.; Yamamura, T.; Sakai, K.; Kunishita, T.;

Tabira, T 370

Thymus Independence of Eosinophilia Induced by a Non-Parasite Antigen

Blomjous, F.J.E.M.; Elgersma, A.; Kruizinga, W.; Ruiten-

berg, E.J $\quad 376$

Induction of c-myc Expression Early in the Course of B Cell-

Activation: Studies in Normal Humans and Patients with

Systemic Lupus erythematosus

Suzuki, H.; Nakanishi, K.; Steinberg, A.; Green, 1380

Route-Dependent Immunomodulation: Local Stimulation by a Surfactant and Systemic

Stimulation by a Polyanion Hilgers, L.A.T.; Snippe, H.; Jansze, M.; Willers, J.M.N. . 388

Synergistic Effects of Synthetic on the Humoral Immune Response Hilgers, L.A.T.; Snippe, H.;

Jansze, M.; Willers, J.M.N. . 392

Proliferative Responses by Immune Murine Popliteal Lymph

Node Cells to High-Molecular-Weight Basic Allergen of

Ryegrass Pollen and Its Cyanogen Bromide Fragments

Ekramoddoullah, A.K.M.; Kisil, F.T.; Cook, R.T.; Sehon,

A.H 397

Cytotoxic Effect of Heterologous and Autologous Serum Factor

on Guinea Pig Thymocytes Assayed by Electronic Cell Vol

ume Distribution Analysis

Sandberg, G.; Stenvinkel, C 404

Comparison of the Histamine-Releasing Action of Substance P on Mast Cells and Basophils

from Different Species and Tissues

Ali, H.; Leung, K.B.P.; Pearce, F.L.; Hayes, N.A.; Foreman,

J.C 413

A Pro-Inflammatory Role of Lymphoid Cells in Acute Pleurisy in Rats Bechara, G.H.; Bates,

M.B.; Dunn, C.J.; Willoughby, D.A. 419

Complement Activation in Human Lymph: Modulation by the Contact Activation System and by

Leukocytes Vogt, W.; Damerau, B., Lühmann, B.; Hesse, D.; Haller, Y. 423

Analysis of Allergen Components in Grass Pollen Extracts using Immunoblotting Haas, H.;

Becker, W.-M.; Maasch, H.J.; Schlaak, M. . . 434

Author Index 441 